\title{
Effect of Biochar of Grass, Chat and Inorganic Fertilizer on the Growth and Yield of Garden Vegetable at Benishangulgumze Region, Ethiopia
}

\author{
Abrham Berta ${ }^{*}$, Tekilil Wolde \\ Department of Natural Resource Management, Wolkite University, Wolkite, Ethiopia \\ Email address: \\ abresh1240@gmail.com (A. Berta),woldetekilil@gmail.com (T. Wolde) \\ ${ }^{*}$ Corresponding author
}

To cite this article:

Abrham Berta, Tekilil Wolde. Effect of Biochar of Grass, Chat and Inorganic Fertilizer on the Growth and Yield of Garden Vegetable at Benishangulgumze Region, Ethiopia. Science Journal of Energy Engineering. Vol. 7, No. 4, 2019, pp. 90-97.

doi: $10.11648 /$ j.sjee.20190704.15

Received: September 19, 2019; Accepted: October 28, 2019; Published: November 9, 2019

\begin{abstract}
Biochar is a relatively recent term used to denote charcoal used as an agricultural input into soils. The idea comes from the use of charcoal in the Amazon on deep, highly leached, and infertile soils by Amazonian peoples in pre-Columbian times. Biochar differs most significantly from charcoal in its primary use; rather than fuel, it is primarily used for the amendment of soils (enhancing their fertility) and sequestration of carbon. One of the distinguishing properties of biochar that allows it to be a long-term carbon sink is its high stability in the environment relative to other types of organic carbon substances. Currently, however, very little or no biochar is utilized in Ethiopia particularly at Benishangulgumze Region for agriculture, in part because of its agronomic value in terms of crop response and soil health benefits have yet to be quantified, and because of the mechanisms by which it improves soil fertility are poorly understood. Therefore, the research is focused on converting the biomass of grasses and chat in to biochar in the process of pyrolysis for yield improvement, soil amendment and environmental pollution reduction. Findings of this research shows environmental pollution that regenerating from chat waste around the town, $\mathrm{CO}_{2}$ gas emission from grass when it is burning become reduced, soil physiochemical properties make improvements by using these waste as biochar instead of throwing everywhere and farmer's cost of buying inorganic fertilizer by using biochar of grass and chat waste as organic fertilizer have significant reduction. Biochar of grass and inorganic fertilizer was required to realize significant increases in fresh marketable bulb yield of onion on the experimental soil. Environmental pollution can reduced through making biochar from the polutants. Chat and grass biochar should used for briquette energy source to save the environment from pollution beside use as fertilizer. Modern technologies are required during preparation of biochar because during making biochar there are gas emit to the atmosphere but can used as ethanol or syngagass for substitute fuels determination of methane formed through decomposing waste of grass and chat is required.
\end{abstract}

Keywords: Biochar, Inorganic Fertilizer, Yield, Vegetable

\section{Introduction}

Biochar is a carbonaceous, dark colored, porous, and predominant stable organic material that is obtained by the pyrolysis of organic waste at higher temperature under low oxygen environment, particularly used for soil amendment $[16,17]$. It is a carbonaceous residue generated by heating biomass in the absence of oxygen, a process known as pyrolysis, which transforms organic matter into a vapor phase and the solid biochar residue. Volatiles generated during pyrolysis remain as syngas or are condensed into biooils, which can be used directly or refined to produce renewable liquid fuels. Application of biochar to the coastal saline soils with appropriate rates reduces nitrogen leaching, keeping soil nitrogen retention, and not increasing ammonia volatilization [12]. Pyrolysis of biochar with moderate temperature results Solid (biochar) is $35 \%$, the liquid (biooil) is $30 \%$ and the remaining is water $[16,17]$.

Use of biochar as a soil amendment is attracting research interest because biochar enhances soil quality and also it is 
considered as means of sequestering carbon, thereby helping to mitigate global climate change [12]. Much biochar research has focused on the effects of biochar in tropical soils, with results indicating improved plant growth, increased nitrogen retention, and increased bioavailability and plant uptake of supplemented nutrients [3]. Example in Midwestern United States increased water retention, increased cation exchange capacity, and raised $\mathrm{pH}$ [11].

The feed stock for the research is tall grass and chat that available in the study area and they are not disposed in appropriate way even they damped on and pollute the environment. Carbon dioxide is captured by a plant through photosynthesis process. On the other hand, carbon from plants is converted to biochar and used as a soil amendment progresses through the carbon cycle much more slowly; radio carbon dating of Amazonian biochar indicates a potential soil residence time measured in 1000s of years [15]. Generally, Biochar's ability to simultaneously act as both soil amendment and carbon sequestration medium provide us with a win-win opportunity that could help reduce atmospheric carbon dioxide in the near future. The research is very crucial for the Benishangul gmuz regional state due to the availability of the feed stock especially grasses which release a large amount of $\mathrm{CO}_{2}$ to the atmosphere through burning and chat pollute the environment by releasing methane gas. Most of Onions are spread throughout the country being cultivated under both irrigated as well as rain fed conditions in different agro climatic regions. The best growing altitude for onions under Ethiopia condition is between 500 and $1500 \mathrm{~m}$ above sea level. Statistics on the production of onion in Ethiopia showed that about 15, 290 ha of the land was cultivated and 0.2 million tones of bulbs were produced in the year 2001/2002 [13]. Among the crops, onion though a recent introduction, is rapidly becoming a popular vegetable crop among consumers. Climate of Benishagul gmuz region is suitable for the growth of onion.

Average attainable yields have declined very much as a result of soil fertility problems. There is evidence of fertilizer use inefficiency especially nitrogen losses from leaching. Most agricultural soils have been degraded due to continued use of unsustainable agricultural tillage mechanisms. This has resulted in acidic soils reducing the crop yield. In rain fed crops there is reduced crop emergence resulting in low population stands reducing the yields. Global increases in carbon dioxide emissions from unsustainable agricultural practices have resulted in global warming and changes in climate. Many feeds stocks, including rice residues, green waste sent to landfills and manure are left to decompose without oxygen in rice paddies, landfills and lagoons [15]. This anaerobic decomposition emits methane $\left(\mathrm{CH}_{4}\right)$. It is also clear that carbon sequestration in the plant body or biomass of the tree takes place in the process of Photosynthesis, but using biomass of plant releases carbon back to the atmosphere.

In the study area grass is burned and waste of chat is thrown to the surrounding environment. So, collecting feedstock of chat and grass for pyrolyzing process to protect environment from pollution of $\mathrm{CO}_{2}$ gas during burning of grass and methane gas during decomposition of chat is taken place. Conducting field experiment (research) on the effect of biochar grass and chat on the yield of onion in the study area is significant in solving the problems likes reducing environmental pollution that regenerating chat waste around the town, $\mathrm{CO}_{2}$ gas emission from grass when it is burning, amending soil phyciochemical properties by using these waste as biochar instead of throwing everywhere and reducing farmer's cost of buying inorganic fertilizer by using biochar of grass and chat waste as organic fertilizer. The research was aimed to compare the effect of biochar grass and chat and inorganic fertilizer on the yield of onion, to determine carbon sequestration potential of chat and grass, to determine the effect of biochar on, CEC, soil $\mathrm{pH}$ and macronutrients levels at planting and harvesting of onion.

\section{Materials and Methods}

\subsection{Study Area Description}

This research was conducted in Benishagul gmuze region of Ethiopia which is $660 \mathrm{~km}$ far from capital of Ethiopia (Adiss Ababa). The region in western Ethiopia and its capital is Assosa. Located in the Asosa Zone, this town has a latitude and longitude of $10^{\circ} 04^{\prime} \mathrm{N} 34^{\circ} 31^{\prime} \mathrm{E} 10.067^{\circ} \mathrm{N} 34.517^{\circ} \mathrm{E}$, with an elevation of 1570 meters (Figure 1). Assosa University is found in the regional State of Benishangul-Gumuz located in Assosa Town in the western part of Ethiopia. The State shares common boundaries in the west with the North \& South Sudan, in the north-east with the State of Amhara, in the east and south with the State of Oromia. Astronomically, Benishangul-Gumuz extends from 08056'8" North to 1200 '27" North latitudes (extending about 03.07180 north to south), and 3403'53" East to 36042'8" East longitudes (extending about 02.63740 west to east) and the university is $2.5 \mathrm{~km}$ in the west with the North of Assosa Town.

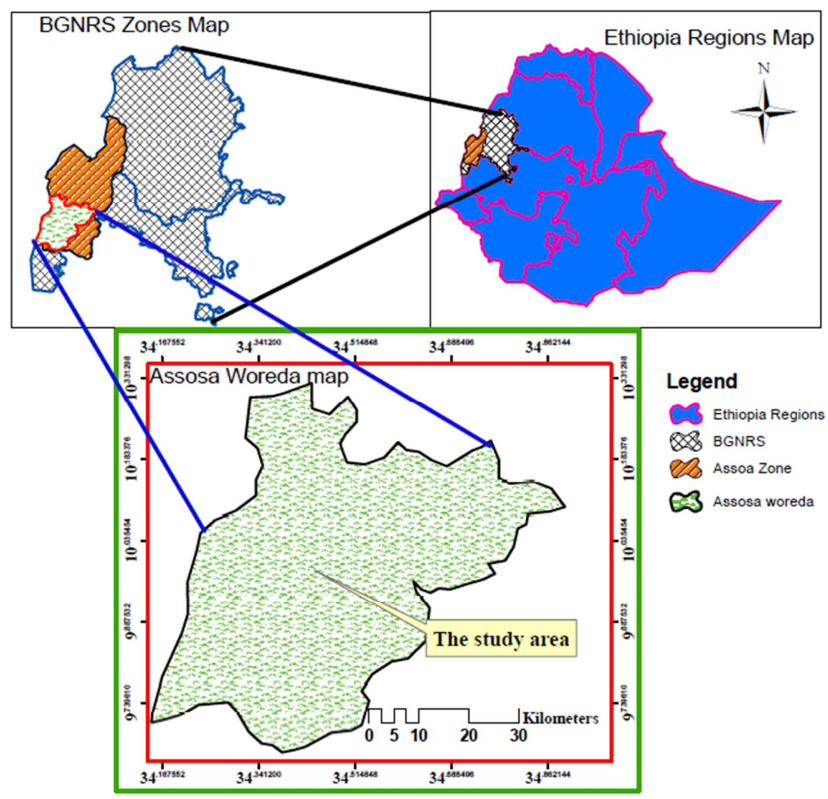

Figure 1. Map of study area: source: ArcGIS version 10.3.1 production. 


\subsection{Methods}

\subsubsection{Soil Sampling and Measurement of Soil Parameters}

Using auger disturbed composite surface soil sample was collected from designed experimental field for soil phyciochemical analysis such as $\mathrm{pH}, \mathrm{Ca}, \mathrm{Mg}, \mathrm{K}, \mathrm{p}, \mathrm{N}, \mathrm{CEC}$, and $\mathrm{OM}$ before input applications in diagonal sampling methods and after harvesting in each plot and then take the value of parameters by following appropriate laboratories procedures. Analysis of both the soil and biochar samples was undertaken at the Addis Ababa national soil laboratories, Ethiopia. PH was measured using FAO potentiometer using a ratio of 1:2.5 extract water; CEC was determined by FAO conductivity -water extract, CEC and exchangeable cations ( $\mathrm{Na} \& \mathrm{~K}$ ) were assessed according to FAO principles using sodium equivalent by flame photometer. The exchangeable cation $(\mathrm{Ca} \& \mathrm{Mg})$ was determined using Ammonium acetate extract - titration, organic carbon (Modified ISO 14235:2015), available sulfur (s) (Turbidimetric).

\subsubsection{Collection of Agronomic Data}

Agronomic observation was recorded during the course of experiment that include days to $70 \%$ maturity, plant height, marketable yield, non-marketable yield and total bulb yield.

Days to $70 \%$ maturity (days): The total numbers of days were counted from the date of transplanting until 70 percent of the plants have attained physiological maturity.

Plant height $(\mathrm{cm})$ : measured from the ground level to the top of a matured plant in each growth stage (initial stage, development stage, mid-stage and late stage).

Marketable bulb yield $\left(\mathrm{t} \mathrm{ha}^{-1}\right)$ : This was recorded as the weight of healthy and marketable bulbs that is greater than $60 \mathrm{~g}$ in size categories.

Unmarketable bulb yield ( $\left.\mathrm{t} \mathrm{ha}^{-1}\right)$ : unmarketable bulb yield is the yield of onion, which is not marketable (under sized, diseased and insect attacked bulbs). It was determined from bulbs harvested from plants in the middle of the experimental plot using digital sensitive balance.

Total bulb yield $\left(\mathrm{t} \mathrm{ha} \mathrm{ha}^{-1}\right)$ : marketable bulb yield and unmarketable bulb yield were summed and expressed in tons $\mathrm{ha}^{-1}$.

\subsection{Treatments and Experimental Design}

A field experiment was conducted in benishagul gmuze region of Ethiopia which around Assosa town to investigate the effect of biochar of grass and chat and inorganic fertilizer on the yield of onion. The experiment consists of four treatments with four replication arranged in completely random block design (CRBD). Totally 16 plot were prepared for field trial and the different treatment for experimentation was assigned as plot with biochar of chat $(\mathrm{Bc})$, plot with biochar of grass $(\mathrm{Bg})$, plot with inorganic fertilizer (IF), plot of controlled $(\mathrm{Wfb})$ plot controlled $(\mathrm{Wfb})$ beside the recommended $150 \mathrm{~kg} / \mathrm{ha}$ urea and $100 \mathrm{~kg} / \mathrm{ha}$ DAP [8] recommended $1.5 \mathrm{~kg} / \mathrm{m}^{2}$ bichar was used [1]. Each treatment was applied in the plot size of $2 \times 2 \mathrm{~m}\left(4 \mathrm{~m}^{2}\right)$ and separated by a distance of $2 \mathrm{~m}$ between a block and $1 \mathrm{~m}$ within a plot. The total field experiment plot was $13 \mathrm{mx} 13 \mathrm{~m}=169 \mathrm{~m}^{2}$. The spacing between plants within row and between rows will be $10 \mathrm{~cm}$ and $20 \mathrm{~cm}$ respectively [8]. With these spacing a plot constitute of 10 rows. For each plot the middle row was used as sampling rows and all data was taken.

Chat feed stock for biochar preparation was collepcted from Assosa town (capital of the region) and grass was collected around /different part of the region. The biochar of grass was prepare at $250^{\circ} \mathrm{C}$ pyrolysis temperature and $550^{\circ} \mathrm{c}$ for chat based on recommendation of [11]. For this study Biochar was prepared by following procedure as (Figure 2) heating the feed stock material at a temperature of $250^{\circ} \mathrm{C}$ over long 10 hours periods of time using oven dry or furnaces through by the process of pyrolysis [12]. After the pyrolysis process, the biochar was grinding to small granules and pass through $2 \mathrm{~mm}$ sieve in order to have the same particle size as that of the soil and finally get the required sample biochar as indicated (Figure 3). Once the biochar has prepared then measure in $\mathrm{kg}$ and according to [1], $6 \mathrm{~kg}$ of biochar was added on $4 \mathrm{~m}^{2}$ plot of land. The researcher also demonstrated to farming community/farmers about the traditional biochar preparation process as (Figure 4) for the sake of resource saving.

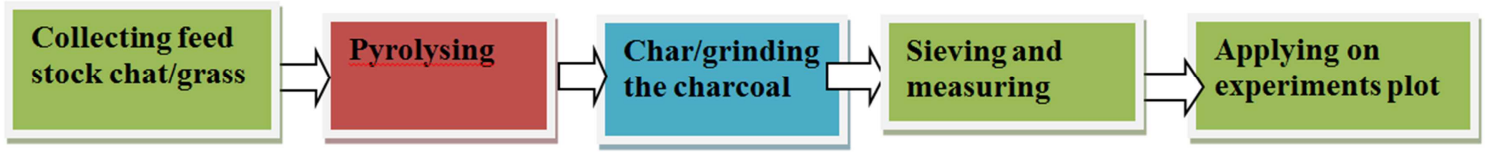

Figure 2. Biochar making process: source: [1].
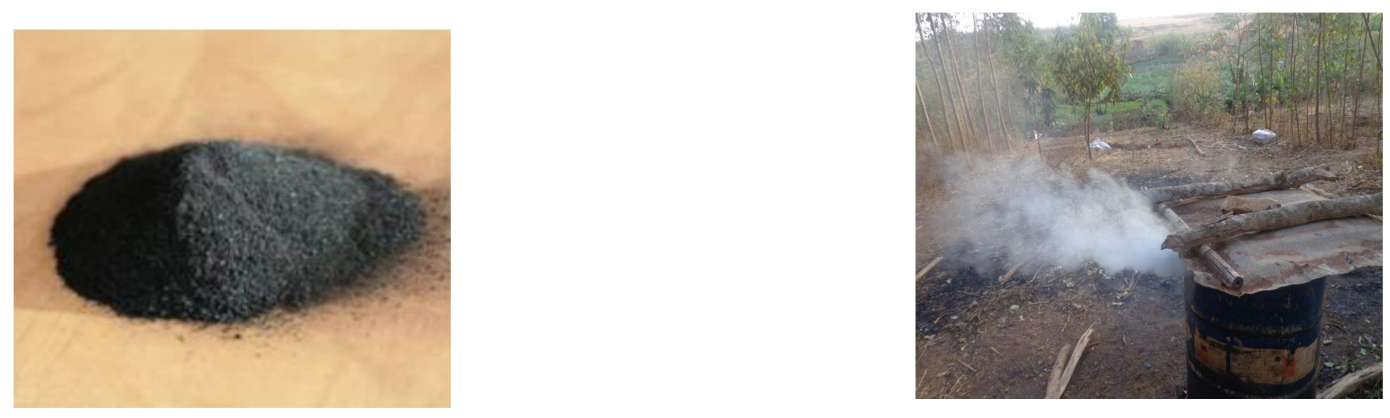

Figure 3. Sample biochar: source [1]. 


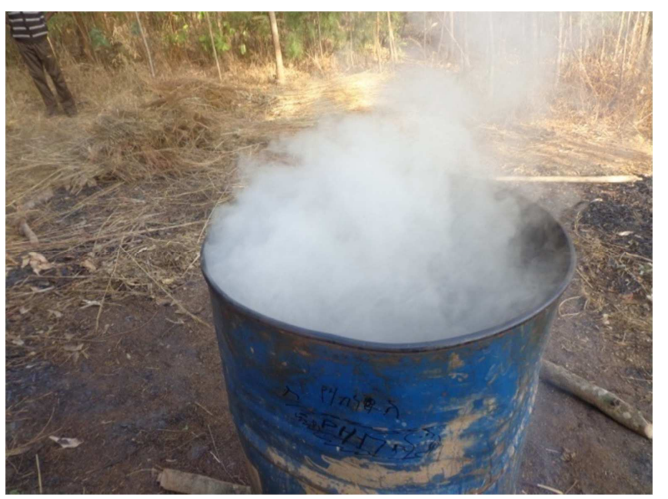

Figure 4. Local /traditional Process of biochar: Study area practice which is well but not known.

\subsection{Carbon Sequestration Grass and Chat}

Hundred grams of evenly mixed sub-samples was brought to the laboratory placing in a sample plastic bag to determine moisture content, from which total dry mass can then be calculated [4]. The steps for measuring grass and chat of biomass of feedstock are as follows: collect the feed stocks; weigh the total weight; dry the feedstock sample using an oven in the laboratory with a temperature of between $70^{\circ} \mathrm{C}$ to $85^{\circ} \mathrm{C}$ until reaching a constant weight; weigh the dryweight; Conduct organic carbon analysis in the laboratory to examine the carbon content.

According to [14], estimation of the amount of biomass in the grass and chat can be calculated by:

$$
L B=\frac{\text { Wfield }}{\mathrm{A}} \times \frac{\text { Wsub_sample }(\text { dry })}{\text { Wsub_sample(fresh })} \times \frac{1}{10,000} \ldots \mathrm{equ}^{\underline{\mathrm{n}}}
$$

Where:

$$
\mathrm{LB}=\text { Litter (biomass of litter } \mathrm{t} \mathrm{ha}^{-1} \text { ) }
$$

$\mathrm{W}_{\text {field }}=$ weight of wet field sample of litter sampled $(\mathrm{g})$;

$\mathrm{A}=$ size of the area in which litter were collected (ha) it is $1 \mathrm{~m} 2$;

W sub-sample, dry = weight of the oven-dry sub-sample of litter taken to the laboratory to determine moisture content (g), and W sub-sample, fresh = weight of the fresh subsample of litter taken to the laboratory to determine moisture content $(\mathrm{g})$.

Carbon stocks in dead litter biomass

$$
\mathrm{C}_{\mathrm{L}}=\mathrm{LB} \times \% \mathrm{C} \cdot \mathrm{equ}^{\mathrm{n}}
$$

Where, $\mathrm{C}_{\mathrm{L}}$ is total carbon stocks in the dead litter in $\mathrm{t} \mathrm{ha}^{-1}, \% \mathrm{C}$ is carbon fraction determined in the laboratory [14].

The structure grass is almost similar in the study area, it mean that similar height and appearances then it is expect to store carbon in different hectares of land. Therefore, 20 sample was taken for carbon determination and also similar for chat.

\subsection{Data Analysis}

After the data collection is completed, the data was organized and recorded on the excel data sheet for easily analysis. The collected or the recorded data was analyzed using R /or SAS software and 5\% significant level and mean separation was tested using LSD.

\section{Results and Discussion}

\subsection{Soil Characteristics}

Data for soil physical and chemical properties under different biochar treatments sampled after onion harvest were presented in Table below. The soil analysis result before the treatment and after the treatment is indicated that changed is occurred due to the variability of application of the treatment. Addition of biochar and fertilizer shows significant amendment on physical-chemical soil parameters. Soil pH was significantly different among soil samples of different treatments. Highest soil $\mathrm{pH}$ (6.74) was found in the experimental unit having inorganic fertilizer treatment while the lowest was found in the controlled (4.92) (Table 1) and ranged from 4.92 to 6.74 . There were significant differences in soil $\mathrm{pH}$ with the control treatment showing lower $\mathrm{pH}$ compared with biochar of grass treatments and inorganic fertilizer. There were statistically significant differences in $\mathrm{pH}$ of grass biochar and inorganic fertilizer treatments as compared with the control treatment, respectively but no significant difference in chat biochar treatment. There was a general trend of increasing soil $\mathrm{pH}$ with increasing biochar and inorganic fertilizer $\left(\mathrm{P}=5.55^{*} 10^{-08}<0.05\right)$. Similarly, soil EC also varied significantly in soil samples obtained from different treatments. The lowest was $0.2 \pm 0.02 \mathrm{dSm}^{-1}$ was found in controlled treatment and the highest was in $0.33 \pm 0.00 \mathrm{dSm}-1\left(\mathrm{P}=07.4 * 10^{-09}, \mathrm{~F}=49.00, \mathrm{DF}=1\right)$. The CEC also has significant treatment effect difference $\left(\mathrm{P}=3.01 * 10^{-07}\right.$ $<0.05)$. Therefore, addition of biochar has equal effect with inorganic fertilizer of soil properties of EC and CEC.

Table 1. Soil pH, EC and CEC analysis after application of treatment biochar and inorganic fertilizer.

\begin{tabular}{llll}
\hline Treatment & PH $^{\mathbf{1}}$ & EC & CEC \\
\hline Control & 4.92 & 0.20 & 16.28 \\
Biochar Chat & 5.38 & 0.23 & 18.23 \\
Biochar Grass & $6.43^{2}$ & 0.32 & 23.08 \\
Inorganic Fertilizer & $6.74^{2}$ & 0.33 & 25.36 \\
\hline
\end{tabular}

Mean separation of the four treatments at $(\mathrm{P} \leq 0.05) .{ }^{2} \mathrm{NS}=$ non-significant.

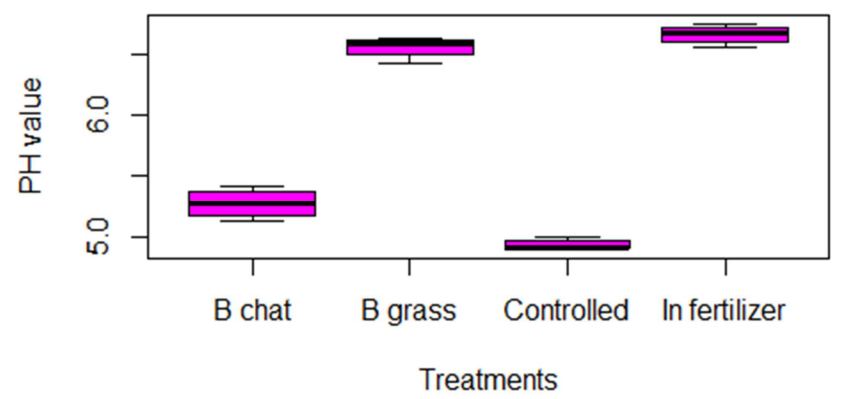

Figure 5. PH of soil with different treatments. 
$\mathrm{R}$ software analysis in the control plot indicated that $\mathrm{pH}$ of application biochar and inorganic fertilizer with grass is having different performance on the soil $\mathrm{pH}$ properties as figure 5. Biochar of chat approaches to have similar $\mathrm{pH}$ with the controlled plot and Biochar of grass approaches to have similar $\mathrm{pH}$ with the inorganic fertilizer plot.

Table 2. Oc, TN, S, TP properties within the treatments.

\begin{tabular}{lllll}
\hline Treatment & $\mathbf{\% O C}$ & TN & S & TP \\
\hline Control & $2.98^{\mathrm{a}}$ & $0.11^{\mathrm{a}}$ & $8.98^{\mathrm{c}}$ & $0.66^{\mathrm{a}}$ \\
Biochar chat & $4.23^{\mathrm{c}}$ & $0.12^{\mathrm{a}}$ & $20.94^{\mathrm{b}}$ & $2.37^{\mathrm{c}}$ \\
Biochar grass & $5.74^{\mathrm{b}}$ & $0.23^{\mathrm{b}}$ & $49.46^{\mathrm{a}}$ & $5.66^{\mathrm{b}}$ \\
Inorganic fertilizer & $4.75^{\mathrm{c}}$ & $0.23^{\mathrm{b}}$ & $49.98^{\mathrm{a}}$ & $5.67^{\mathrm{b}}$ \\
\hline
\end{tabular}

Mean separation of the four treatments at $(\mathrm{P} \leq 0.05)$. Similar letter $=$ nonsignificant.

Table 3 revealed that there were significance differences in soil organic matter (SOM) among the treatments. The effect of inorganic fertilizer and biochar of grass on addition of SOM was generally consistent but the biochar of grass exerted considerable influence than all treatment on the accumulation of SOM. The residual SOM content after onion harvest were in treatments receiving the highest level of biochar. The values for SOM increased with adding of biochar than inorganic fertilizer since it was significance difference between the two treatment $(\mathrm{P}<0.05)$. Since soil organic matter is directly proportion to percent of organic carbon and indicating that the soil carbon sequestration is higher in grass biochar than inorganic fertilizer.

Differences in soil mineral $\mathrm{N}$ level between inorganic fertilizer and biochar grass treatments were not significant $(\mathrm{P}>0.05)$ but there were significant difference between the control and both biochar grass and inorganic fertilizer $(\mathrm{P}<$ 0.05 ). The soil mineral $\mathrm{N}$ was generally greater in treatments receiving biochar grass and inorganic fertilizer but lower the biochar of chat $(\mathrm{P}>0.05)$. However the effect of biochar chat on soil mineral $\mathrm{N}$ was inconsistent and were not remarkable comparing with controlled treatment. The results suggested that both biochar and inorganic fertilizer had considerable influence on accumulation of soil mineral N (Figure 6). The minimum and maximum amount of Nitrogen 0.09 (controlled plot) and $0.47 \%$ (biocha grass plot), respectively and its mean is $0.26 \%$.

\section{Plot of treatment vs.TN}

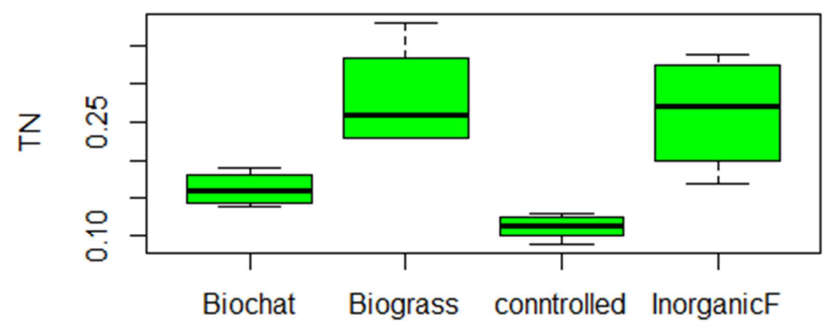

treatment

Figure 6. Total Nitrogen Difference with Treatments.
Table 4. $\mathrm{Na}, \mathrm{Ca}, \mathrm{Mg}$ content with the treatment.

\begin{tabular}{llll}
\hline treatment & $\mathbf{N a}$ & $\mathbf{C a}$ & $\mathbf{M g}$ \\
\hline Control & $0.07^{\mathrm{a}}$ & $2.83^{\mathrm{a}}$ & $2.83^{\mathrm{c}}$ \\
Biochar chat & $0.21^{\mathrm{b}}$ & $8.98^{\mathrm{b}}$ & $4.98^{\mathrm{a}}$ \\
Biochar grass & $0.65^{\mathrm{c}}$ & $12.7^{\mathrm{c}}$ & $7.47^{\mathrm{b}}$ \\
Inorganic fertilizer f & $0.68^{\mathrm{c}}$ & $11.57^{\mathrm{c}}$ & $7.23^{\mathrm{b}}$ \\
\hline \multirow{2}{*}{$\begin{array}{l}\text { Mean separation of the four treatments at }(\mathrm{P} \leq 0.05) . \\
\text { significant. }\end{array}$}
\end{tabular}

Table 3 also indicated that there were significance differences in soil sodium content $(\mathrm{Na}=0.68)$ compared with biochar of chat (0.21) and zero treatments (control plot=0.07). The effect of inorganic fertilizer and biochar of grass was generally consistent but the biochar of grass exerted considerable influence than all treatment on the increase of Na content. Generally biochar applications and inorganic fertilizer utilization had better improvement on soil $\mathrm{Na}, \mathrm{Ca}$ and $\mathrm{Mg}$ contents.

\subsection{Carbon Sequestration in Chat and Grass}

From the fixed sample of grass, the biomass that obtained was $0.18 \mathrm{ton} / \mathrm{ha}$. Therefore, the carbon stock in grass is 0.08 ton/ha. This indicated that the total carbon sequestration of grass is $3.67 * 0.08=0.29$ ton $/$ ha. When burning of grass, there is emission of 0.029 ton/ha of $\mathrm{CO}_{2}$ to the atmosphere or probability of forming methane is high because unaerobically degrading of grass is high.

\subsection{Characterization of Treatment with Plant Parameters}

The research analysis indicated that onion with treatment of grass and inorganic fertilizer is almost the same but treatment with chat yield is low since the chat nutrient content is toxic for plant growth.

\subsubsection{Days to 70\% Maturity}

Days to maturity can illustrate the response of plants where by growing under unfavorable condition tried to make adjustments with the environment through modification of their normal physiological growth, development processes and morphological behavior under non-conducive conditions in order to assure and maintain the continued survival of the species. Table 4 indicates that there was significant effect ( $P$ $\leq 0.01$ ) on days to $70 \%$ maturity of the crop due to the application of biochar of grass, and inorganic fertilizer compared to that of bichar of chat and zero plot. The highest number of days to $70 \%$ maturity was recorded in plots with bichar of grass (117.30 days) and the lowest (112.50 days) was recorded in plots of bochar chat treatment. The result clearly indicates that days to maturity were prolonged in response to increased levels of treatment application. This may be attributed to the role that different treatments play in promoting vegetative growth before the start of bulb development, that nitrogen manure application promotes vegetative and lush growth thereby delaying plant maturity this was in line with the suggestion given by $[9,6]$. However, application of bichar of chat had not a significant difference $(\mathrm{P}>0.01)$ on days of plant maturity compared to in zero 
treatment plots.
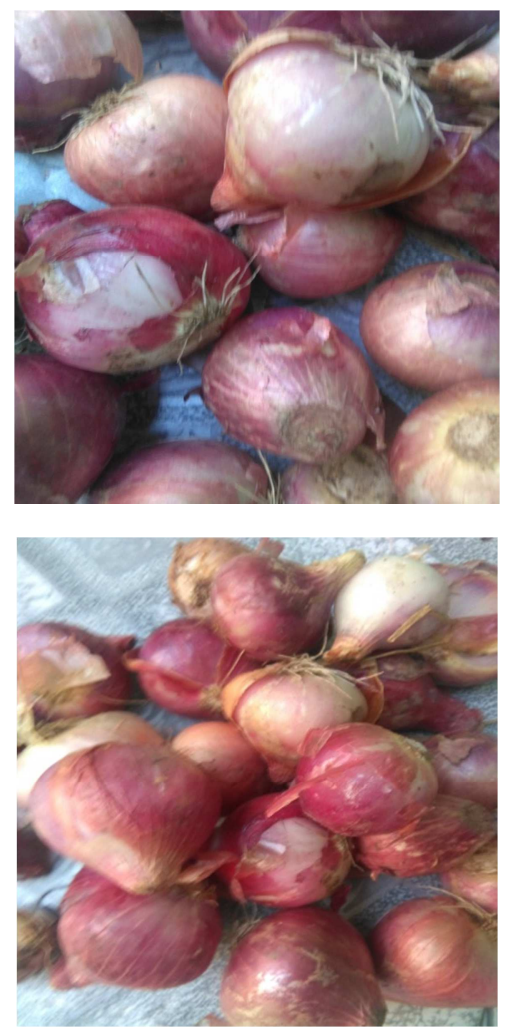

Figure 7. Bulbs Grown by Controlled Plot: output of the experiment.

\subsubsection{Plant Height}

The highest height was recorded in inorganic fertilizer treatment which is $0.55 \mathrm{~cm}$ followed by grass treatment $0.50 \mathrm{~cm}$ and the lowest is zero treatment. Table 4 also revealed that plant height at different growth stages (initial, mid, development and late stage). There were a significant height $(\mathrm{P} \leq 0.01)$ difference in plots with biochar of chat and that of inorganic fertilizer compared to all treatments and the highest plant height also recorded here in all stages of the crop. But there was no significant height difference in application of biochar of chat and plots of no treatment. Plant height was also significantly different in each growth stage but no significant height difference was found during development and late stages. This could be due to the crop was under way for the development of bulb and growth of the plant was ceased $[5,6]$.
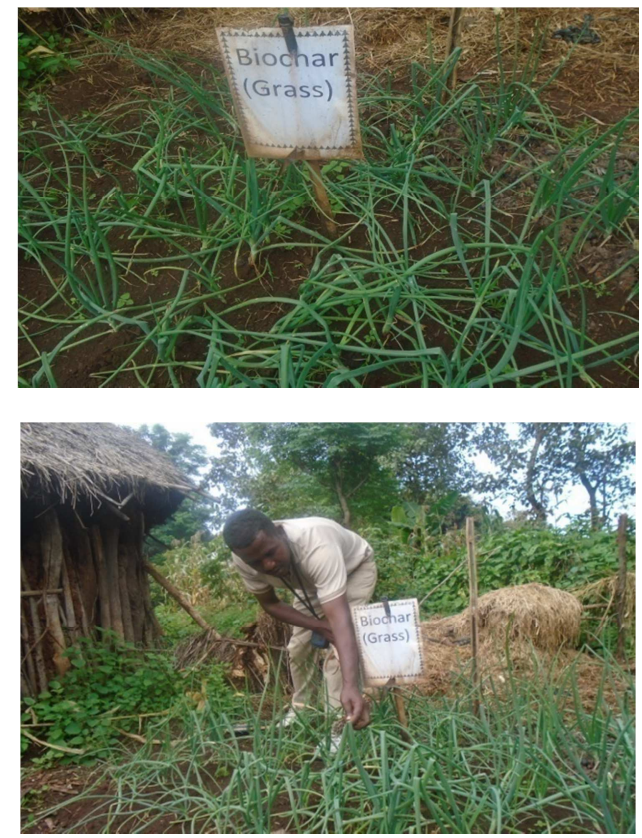

Figure 8. Onions with Treatment of Grass biochar: Field applications and caring.

Table 5. Treatment effects on plant maturity and plant height at different growth stages.

\begin{tabular}{|c|c|c|c|c|c|c|c|c|c|c|}
\hline \multirow{2}{*}{ Treatment } & \multicolumn{2}{|c|}{$70 \%$ maturity } & \multicolumn{2}{|l|}{ PHI } & \multicolumn{2}{|l|}{ PHII } & \multicolumn{2}{|l|}{ PHIII } & \multicolumn{2}{|l|}{ PHIV } \\
\hline & Mean \pm SE & $\mathrm{CV}$ & Mean \pm SE & $\mathrm{CV}$ & Mean \pm SE & CV & Mean \pm SE & CV & Mean \pm SE & CV \\
\hline $\mathrm{Wfb}$ & $113.3^{\mathrm{a}} \pm 0.31$ & 1.5 & $37.1^{\mathrm{b}} \pm 0.05$ & 1.02 & $47.1^{\mathrm{b}} \pm 0.05$ & 1.02 & $58.0^{\mathrm{b}} \pm 0.63$ & 1.09 & $58.5^{\mathrm{b}} \pm 0.03$ & 1.01 \\
\hline $\mathrm{Bc}$ & $112.5^{\mathrm{a}} \pm 0.33$ & 1.52 & $37.0^{\mathrm{b}} \pm 0.23$ & 1.10 & $47.3^{\mathrm{b}} \pm 0.01$ & 1.04 & $58.6^{\mathrm{b}} \pm 0.08$ & 1.26 & $58.0^{\mathrm{b}} \pm 0.14$ & 1.04 \\
\hline $\mathrm{Bg}$ & $116.3^{\mathrm{b}} \pm 0.33$ & 1.51 & $37.1^{\mathrm{b}} \pm 0.01$ & 1.05 & $48.1^{\mathrm{c}} \pm 0.01$ & 1.05 & $58.7^{\mathrm{b}} \pm 0.03$ & 1.10 & $58.6^{\mathrm{b}} \pm 0.08$ & 1.23 \\
\hline If & $117.3^{\mathrm{b}} \pm 0.13$ & 1.49 & $38.0^{\mathrm{c}} \pm 0.02$ & 1.10 & $49.0^{\mathrm{d}} \pm 0.08$ & 1.03 & $60.1^{\mathrm{c}} \pm 0.02$ & 1.06 & $60.0^{c} \pm 0.21$ & 1.06 \\
\hline
\end{tabular}

Note: Treatment means within a column followed by the same letter are not significantly different at $p \leq 0.01$

PHI=plant height at initial stage, $\mathrm{PHII}=$ plant height at mid-stage, $\mathrm{PHIII}=$ plant height at development stage, $\mathrm{PHIV}=$ plant height at late stage, wfb= without inorganic fertilizer and biochar, $\mathrm{Bc}=$ biochar of chat, $\mathrm{Bg}=$ biochar of grass, If $=$ inorganic fertilizer.

\subsubsection{Marketable Fresh Bulb Yield}

The analysis of variance indicates that the main effects of biochar at $(\mathrm{P}<0.01)$ and the main effect of inorganic fertilizer was significant $(\mathrm{P}<0.01)$ on marketable fresh bulb yield (Table 5). The table also shows the biochar of grass and inorganic fertilizer was required to realize significant increases in fresh marketable bulb yield of onion on the experimental soil beside field treatment or management which was taken by the field worker and the researchers as well as (Figure 8). Corroborating in these results [7], also reported applications of fertilizer specially that poultry manure at the rates of 2.47-4.94 $\mathrm{t} \mathrm{ha}^{-1}$ either alone or in combination with synthetic fertilizer produced acceptable yields of marketable onions. Therefore, the highest $(28.96 \mathrm{t}$ /ha) marketable yield was recorded on plot with inorganic fertilizer whereas the lowest $(25.30 \mathrm{t} / \mathrm{ha})$ was observed on plot with biochar of chat treatment.

\subsubsection{Unmarketable Yield}

The result obtained from this experiment was also in accord with that of [10] who reported that untreated plot and those treated with high level of organic fertilizer produced maximum number of unmarketable bulbs and marketable yield respectively. This may be attributed to small-sized bulbs produced in the untreated plots due to nutrient 
deficiency as (Figure 7). Then, the highest (4.02 t /ha) unmarketable bulb yield was recorded on plot of no treatment but the lowest $(2.82 \mathrm{t} / \mathrm{ha})$ was indicated on plot with applications of inorganic fertilizer and total bulb yield was the sum of unmarketable and marketable yield, then the highest (31.78 t/ha) was recorded on plot with inorganic fertilizer application (Table 5).

Table 6. Effect of applied treatment on yield components.

\begin{tabular}{llllll}
\hline \multirow{2}{*}{ treatment } & MY ton $/$ ha & & UNMY ton $/$ ha & \multicolumn{2}{c}{ TY ton $/$ ha } \\
\cline { 2 - 6 } & Mean \pm SE & CV\% & Mean \pm SE & CV\% & Mean \pm SE \\
\hline Wfb & $25.51^{\mathrm{b}} \pm 0.07$ & 1.87 & $4.02^{\mathrm{a}} \pm 0.02$ & 1.87 & $29.54^{\mathrm{a}} \pm 0.05$ \\
$\mathrm{Bc}$ & $25.30^{\mathrm{b}} \pm 0.05$ & 1.02 & $3.14^{\mathrm{b}} \pm 0.02$ & 1.32 & 1.11 \\
$\mathrm{Bg}$ & $28.24^{\mathrm{a}} \pm 0.01$ & 1.08 & $2.93^{\mathrm{c}} \pm 0.02$ & 1.23 & 1.11 \\
$\mathrm{If}$ & $28.96^{\mathrm{a}} \pm 0.02$ & 1.18 & $2.82^{\mathrm{c}} \pm 0.08$ & 1.42 & $31.17^{\mathrm{b}} \pm 0.02$ \\
\hline
\end{tabular}

Note: Treatment means within a column followed by the same letter are not significantly different at $\mathrm{p} \leq 0.01 \mathrm{Hint}$ : MY=marketable yield, UNMY $=$ unmarketable yield, TY $=$ total yield

$\mathrm{Wfb}=$ without inorganic fertilizer and biochar, $\mathrm{Bc}=$ biochar og chat, $\mathrm{Bg}=$ biochar of grass, If $=$ inorganic fertilizer

\section{Conclusion and Recommendation}

Unabsorbed nitrogen fertilizer is carried away by water runoff into lakes and rivers, resulting in eutrophication, or is converted into gaseous nitrous oxide by soil bacteria, contributing to acid rain. However, since biochar consists mostly of unmanageable aromatics rather than bio available amines, it cannot directly provide nitrogen to crops as most conventional fertilizers. Instead, biochar inhibits the leaching of nitrogen compounds and affects the availability of nitrates and ammonia in the soil. Laboratory analysis for the yield of onion or after collection of the yield is required grass can substitute for inorganic fertilizer, awareness creation maximization of grass biochar used as fertilizer. Environmental pollution can reduced through making biochar of grass. Chat biochar should used for briquette energy source to save the environment from pollution rather than fertilizer. Modern technologies are required during preparation of biochar because during making biochar there are gas emit to the atmosphere but can used as ethanol or syngagass for substitute fuels determination of methane formed through decomposing of waste of grass and chat is required.

\section{References}

[1] Albert., 2010. The Biochar Solution: Carbon Farming and Climate Change. New Society Publishers. ISBN: 9780865716773 .

[2] Ami Z., 2011. Biochar a sustainable waste management solution and effective soil amendment for cacao growers in Central America. Carbon Gold / 07950721021.

[3] Atkinson, C. J., Fitzgerald, J. D., and Hipps, N. A., 2010. Potential mechanisms for achieving agricultural benefits from biochar application to temperate soils: A review. Plant Soil 337:1-18.

[4] Bhishma, P. S., Shiva, S. P., Ajay, P., Eak, B. R., Sanjeeb, B., Tibendra, R. B., Shambhu, C., and Rijan, T., 2010. Forest Carbon Stock Measurement: Guidelines for measuring carbon stocks in community-managed forests. Funded by Norwegian Agency for Development Cooperation (NORAD). Asia Network for Sustainable Agriculture and Bioresources
(ANSAB) publishing, Kathmandu, Nepal, pp. 17-43.

[5] Bryan, H. 2011. Biochar - An Organic House for Soil Microbes, Sisaket Province, Thailand.

[6] Deenik, JL., McClellan, T., Uehara, G., Antal, MJ., Campbell, S., 2010. Charcoal volatile matter content influences plant growth and soil nitrogen transformations. Soil Sci Soc Am J 74: $1259-1270$.

[7] Dumroese, R. K., Heiskanen, J., Englund, K., and Tervahauta, A., 2011. Pelleted biochar: Chemical and physical properties show potential use as a substrate in container nurseries. Biomass Bioenerg. 35:2018-2027.

[8] EIAR, 2004. Effect of cattle manure on soil erosion by water. soli sci.133:228-231 Ethiopia Central Statistical Authority. Ethiopian Population Census. Addis Ababa. E. C; 1994.

[9] Gaskin, JW., Speir, RA., Harris, K., Das, KC., Lee, RD., Morris, LA., Fisher, DS., 2010. Effect of peanut hull and pine chip biochar on soil nutrients, corn nutrient status, and yield. Agron J 102:623-633.

[10] Genxing P., David C., Lehmann J., 2011. Burn to air or burial in soil: The fate of China's straw residues Nanjing Agricultural University, Nanjing 210095-China; University of California Riverside, CA 92521, USA; §Cornell University, Ithaca, NY 14853, USA.

[11] Laird, D. A., P. D. Fleming, D. D., Davis., R., Horton. B., Wang., and D. L. Karlen., 2010a. Impact of biochar amendments on the quality of a typical Midwestern agricultural soil. Geoderma 158:443-449.

[12] Laird, D. A., P. D. Fleming., D. L. Karlen., B. Wang., and R. Horton., 2010b. Biochar impact on nutrient leaching from a Midwestern agricultural soil. Geoderma 158:436-442.

[13] Logan Cochrane and Yeshtila W. Bekele, 2017: Average crop yield (2001-2017) in Ethiopia: Trends at national, regional and zonal levels.

[14] Pearson, T. R., Walker, S., and Brown, S., 2005. Sourcebook for land-use, land-use change and forestry projects. Winrock International and the Bio-carbon fund of the World Bank. Arlington, USA, pp. 19-35.

[15] Sun H, Lu H, Chu L, Shao H, Shi W 2017: Biochar applied with appropriate rates can reduce $\mathrm{N}$ leaching, keep $\mathrm{N}$ retention and not increase $\mathrm{NH} 3$ volatilization in a coastal saline soil. Sci. Total Environ., 575, 820 825.10.1016/j.scitotenv.2016.09.137 
[16] Verheijen F, Jeffery S, Bastos AC, Van Der Velde M, Diafas I 2010: Biochar Application to Soils. A Critical Scientific Review of Effects on Soil Properties, Processes, and Functions.
[17] Zhang J, Liu J, Liu R 2015: Effects of pyrolysis temperature and heating time on biochar obtained from the pyrolysis of straw and lignosulfonate. Bioresour. Technol., 176, 288-291. 10.1016/j. biortech.2014.11.011 